NBER WORKING PAPER SERIES

SECULAR STAGNATION IN THE OPEN ECONOMY

Gauti B. Eggertsson

Neil R. Mehrotra

Lawrence H. Summers

Working Paper 22172

http://www.nber.org/papers/w22172

\author{
NATIONAL BUREAU OF ECONOMIC RESEARCH \\ 1050 Massachusetts Avenue \\ Cambridge, MA 02138 \\ April 2016
}

This paper is forthcoming in the American Economic Review, Papers and Proceeding, May 2016. It was presented at the January 2016 AEA meetings in the session: "Global Reserve Assets in a Low Interest Rate World." We thank Matteo Maggiori for helpful comments. The views expressed herein are those of the authors and do not necessarily reflect the views of the National Bureau of Economic Research.

NBER working papers are circulated for discussion and comment purposes. They have not been peer-reviewed or been subject to the review by the NBER Board of Directors that accompanies official NBER publications.

(C) 2016 by Gauti B. Eggertsson, Neil R. Mehrotra, and Lawrence H. Summers. All rights reserved. Short sections of text, not to exceed two paragraphs, may be quoted without explicit permission provided that full credit, including $\odot$ notice, is given to the source. 
Secular Stagnation in the Open Economy

Gauti B. Eggertsson, Neil R. Mehrotra, and Lawrence H. Summers

NBER Working Paper No. 22172

April 2016

JEL No. E31,E52,F3,F44

\begin{abstract}
Conditions of secular stagnation - low interest rates, below target inflation, and sluggish output growth - now characterize much of the global economy. We consider a simple two-country textbook model to examine how capital markets transmit secular stagnation and to study policy externalities across countries. We find capital flows transmit recessions in a world with low interest rates and that policies that trigger current account surpluses are beggar-thy-neighbor. Monetary expansion cannot eliminate a secular stagnation and may have beggar-thy-neighbor effects, while sufficiently large fiscal interventions can eliminate a secular stagnation and carry positive externalities.

Gauti B. Eggertsson

Department of Economics

Brown University

64 Waterman Street

Providence, RI 02912

and NBER

gauti_eggertsson@brown.edu

Neil R. Mehrotra

Department of Economics

Brown University

64 Waterman Street

Providence, RI 02906

neil_mehrotra@brown.edu

Lawrence H. Summers

Harvard Kennedy School of Government

79 JFK Street

Cambridge, MA 02138

and NBER

lhs@harvard.edu
\end{abstract}


The disappointing recovery of the US and other advanced economies in the wake of the Great Recession and the tendency for periods of adequate growth to involve unstable finance has resurrected interest in Alvin Hansen's idea of secular stagnation (Summers (2014)). The argument is that the industrial world is plagued by an increasing propensity to save and a declining propensity to invest. The result is a declining equilibrium real interest rate, a tendency for lower bounds on interest rates to constrain their ability to find equilibrium levels, and a consequent persistence of inadequate demand leading to slow growth, sub-target inflation, and excessive non-employment. A defining element of secular stagnation theories is that, unlike the many analyses of liquidity trap situations in the tradition of Krugman (1998) in which it is assumed, there is no deus ex machina that will return the economy to a situation of positive real interest rates at some future point. This now appears highly plausible. Average long-term interest rates around the industrial world are now lower than they were five years ago in the immediate aftermath of the crisis.

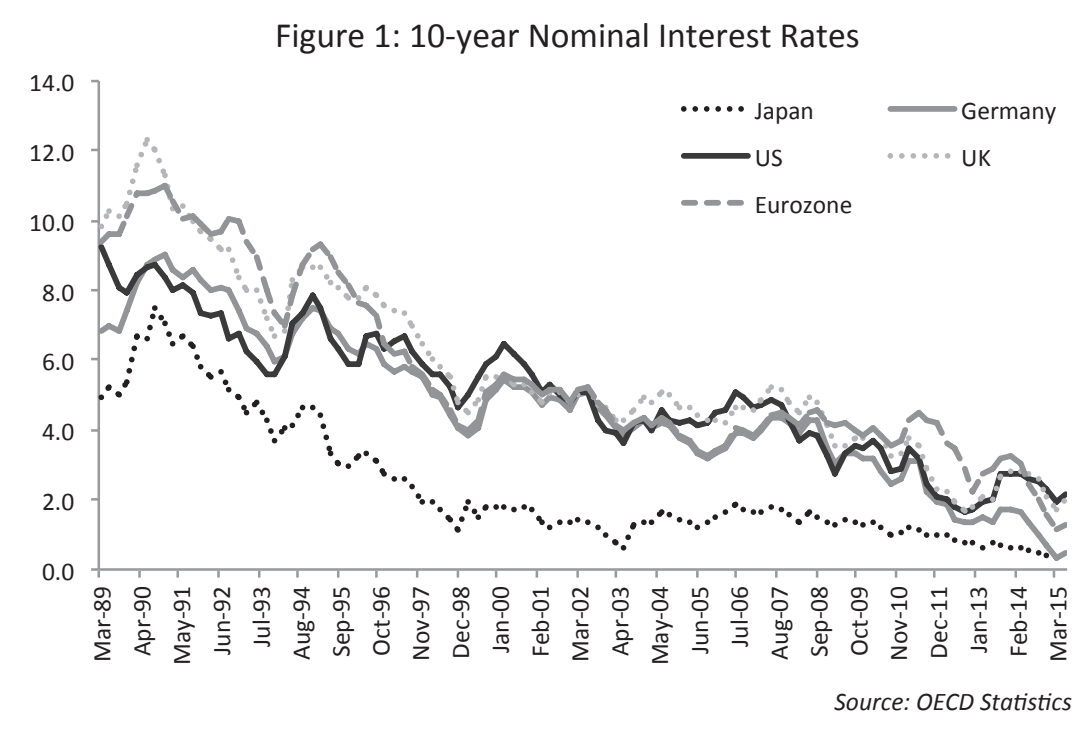

As this is written, financial markets suggest that inflation is expected to remain well below its 2 percent target for well over a decade in the United States, Europe and Japan, and that real interest 
rates are likely to remain well below 1 percent into the indefinite future. Figure 1 shows the continuous drop in longer-term interest rate over the past quarter of a century. ${ }^{2}$

Much of the discussion of secular stagnation has taken place in the context of closed economy models. Yet declining real interest rates have been observed throughout the industrialized world as illustrated in Figure 1, and it is clear that capital flows to and from developing markets are large enough to impact their level on a global basis. Figure 2 illustrates that the decline in interest rate across the globe has been associated with large swings in the current account across countries, with the US being the largest deficit country. There is some recent indication, as illustrated in Figure 3, that capital flight from emerging markets has increased recently. So it seems important to understand issues related to secular stagnation in a global context.

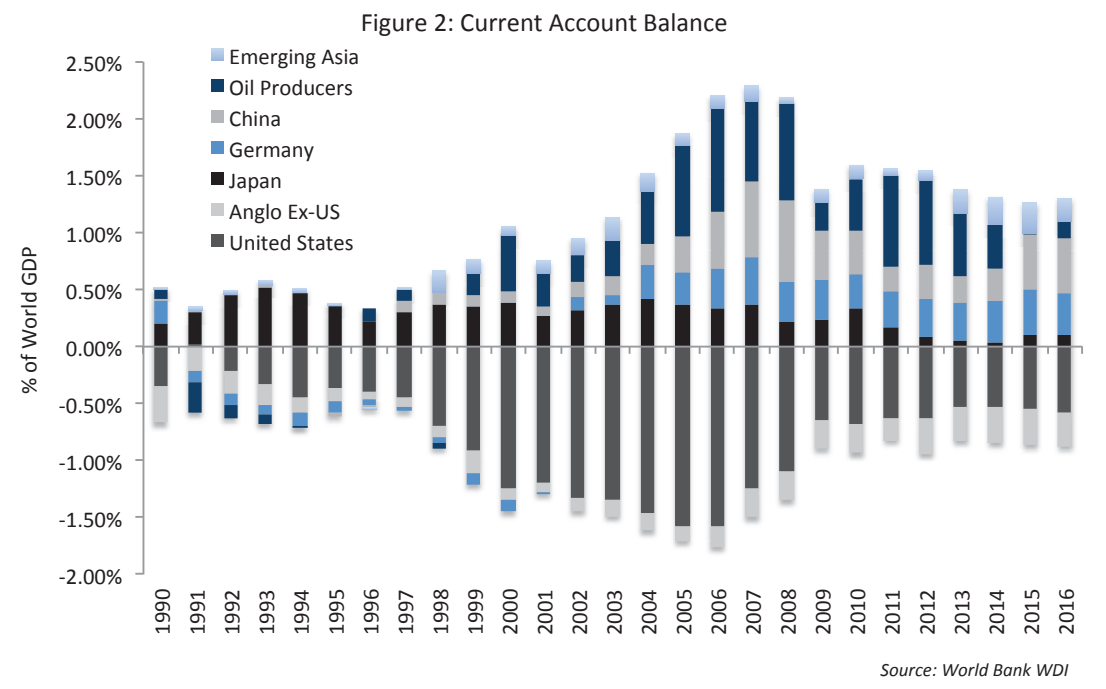

Building on Eggertsson and Mehrotra (2014), Eggertsson, Mehrotra, Singh, and Summers (2016, EMSS hereafter) analyze an open economy, optimizing, overlapping generations model in which equilibrium real interest rates can permanently be negative. They consider the impacts of various kinds of shocks to saving and investment in an international context and note how the prospect that interest rates are constrained by a lower bound alters a variety of traditional results

\footnotetext{
2 The figure above displays nominal five year rates, as measured by government bond yields, since inflation rates have been relatively stable in this period the real rate displays the same pattern.
} 
on linkages in the open economy. Caballero, Farhi and Gourinchas (2015) provide a closely related analysis in a context where interest rates are held down because of a demand for safe assets rather than an excess of saving.

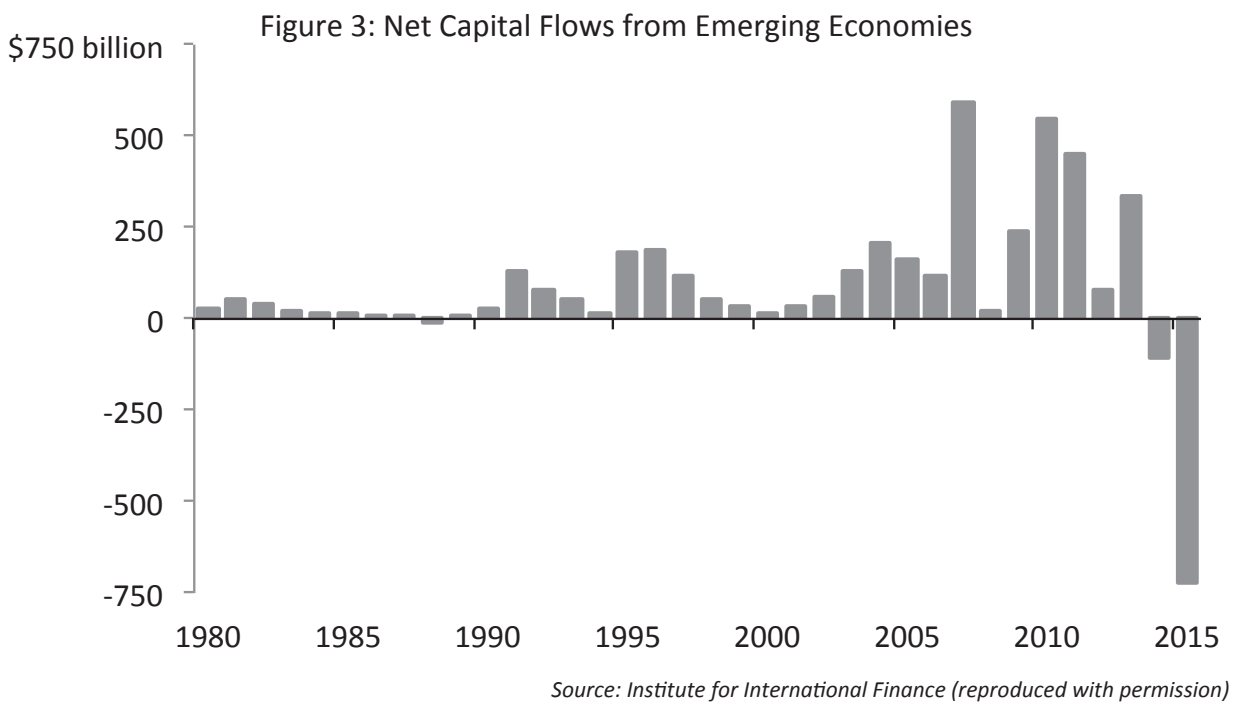

With the comfort provided by this earlier work in the context of optimizing models, this paper takes up the policy implications of secular stagnation in the open economy in the context of a textbook IS-MP model similar to the one introduced by Romer (2013). We reach two primary conclusions. First, secular stagnation risks magnifying the importance of international linkages and the gains from policy coordination. In particular we show that capital inflows can have strong negative externalities for a country constrained by the zero lower bound, a result reminiscent of neo-merchantilism. Second, recognizing open economy considerations reinforces the case for primary reliance on fiscal rather than monetary policies in combatting secular stagnation.

Section I sketches the model. Section II uses the model to consider a range of shocks and policy changes. Section III addresses possible objections and generalizations and considers the current policy context. 


\section{A Simple Model}

We consider a simple variation of a two country IS-MP framework focusing on the case where interest rates in at least one country are constrained by the zero bound. There are two countries, home and foreign each satisfying an investment-savings (IS) equation, a monetary policy Taylor rule (MP) augmented by the zero lower bound on the nominal interest rate (ZLB), and an aggregate supply equation (AS): ${ }^{3}$

$$
\begin{gathered}
Y=-\alpha(i-\pi)+\delta G-\chi q-\omega K^{*}+\theta\left(B^{g}-I R\right)+\varepsilon \\
i=\max \left(0, r^{f}+\bar{\pi}+\phi_{\pi}(\pi-\bar{\pi})\right) \\
Y=\left\{\begin{array}{l}
Y^{f}, \pi \geq 0 \\
\kappa \pi, \pi<0
\end{array}\right.
\end{gathered}
$$

where $\gamma, \alpha, \omega, \theta, \kappa, \delta>0$ and $\phi_{\pi}>1$ are parameters, $\bar{\pi}$ is the inflation target, $Y$ is output, $i$ is the short-term nominal interest rate, $\pi$ is inflation, $G$ is government spending, $q$ is the real exchange rate, $K^{*}$ is the real value of the assets of foreigners in the domestic economy, $B^{g}$ is government debt and $I R$ is international reserves of the foreign government held in domestic government bonds. For now, the domestic real interest rate, $r \equiv i-\pi$, is assumed to be higher than the foreign real interest rate $r^{*}$, hence private savings are flowing from abroad to the home country. $r^{f}$ and $Y^{f}$ are the real interest rate and output consistent with full employment, often referred to as natural or neutral rates. While $Y^{f}$ is a fixed constant, $r^{f}$ depends on exogenous and policy variables and is determined by the $I S$ equation by setting $Y=Y^{f}$. $\varepsilon$ is a composite of secular terms. $^{4}$

\footnotetext{
${ }^{3}$ While largely analogous to the textbook setup, this set of equations can be derived by a log-linearization of the steady state of the model in EMSS if changes in public debt or government spending are financed by a tax on the working age population and the real exchange rate is fixed. Note that once the real exchange rate is endogenous, one needs one additional equation to close the model, which in textbook treatments is typically a balance of payments equation.

${ }^{4}$ Eggertsson and Mehrotra (2014), for example, show how lower population or productivity growth, an increase in income inequality, a debt deleveraging shock, or a fall in the relative price of investment goods can generate this shock.
} 
The foreign economy satisfies the same set of equations where we denote each variable by * except that the signs in front of $q$ and $K^{*}$ are now positive. We generally think of $K^{*}$ as an increasing function of the spread between the two interest rates: $K^{*}=f\left(r-r^{*}\right) .^{5}$ In the equations above, we assume interest rates are higher at home; if they are instead higher abroad, then capital flows from home to abroad so that $K^{*}<0$.

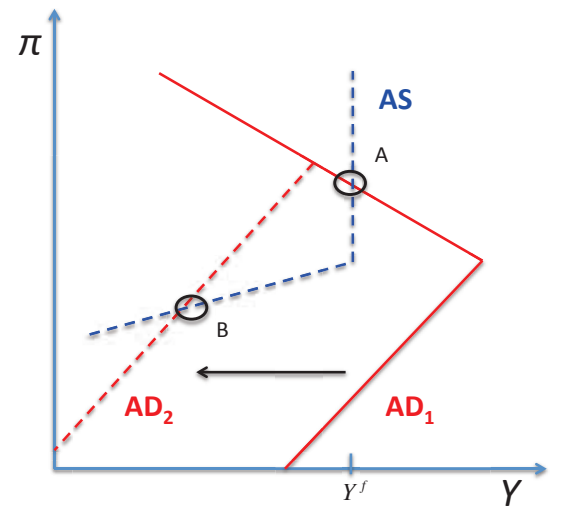

Figure 4

Figure 4 plots the aggregate demand (AD) curve - MP and IS combined - and the aggregate supply (AS) curve for the domestic economy taking $K^{*}$ and $q$ as given. When the nominal interest rate is positive, the $\mathrm{AD}$ curve is downward sloping, as the central bank cuts the nominal interest rate more than one to one in response to inflation below target, lowering real rates and increasing demand. However, there is a limit to how far the central bank can lower rates due to the ZLB. At the ZLB, the AD curve kinks and becomes upward sloping. Since nominal rates are stuck at zero, lower inflation now raises real interest rates, thereby reducing demand. The AS curve is relatively standard: there is a trade-off between inflation and output until full employment is reached and output equals its full employment level. ${ }^{6}$ If the domestic natural

\footnotetext{
5 We assume that $f\left(r-r^{*}\right)=\bar{K}^{*}+\eta\left(r-r^{*}\right)$ in our experiment below where $\bar{K}^{*}$ is a constant, and we will consider comparative statics on that variable. If $\bar{K}^{*}$ is high enough, there is perfect capital integration with $r=r^{*}$.

${ }^{6}$ EMSS show how this AS relation can be derived with partial downward wage rigidity.
} 
interest rate is sufficient high $\left(r^{f} \geq-\bar{\pi}\right)$, the AD and AS curves intersect on the vertical segment of the AS curve (point A), with a positive nominal rate, output at its full-employment level, and inflation at target. However, if the natural rate is too low, this intersection point falls on the other side of the kink point (B); the domestic economy finds itself in secular stagnation - a steady state characterized by a binding ZLB, inflation below target, and a persistent output gap.

How does an economy find itself in a secular stagnation? The IS curve determines the equilibrium real interest rate in the domestic bond market for a given level of output. A secular stagnation occurs when the real interest rate with output at full employment - the natural rate of interest - is sufficiently negative so that the ZLB is binding $\left(r^{f}<-\bar{\pi}\right)$. Forces that increase loan supply shift back the IS curve and lower the natural rate of interest, e.g., foreign capital inflows. Forces that reduce loan demand shift back the IS curve by reducing the natural rate of interest, e.g., tighter fiscal policy.

A useful way to think about a secular stagnation is that it corresponds to a situation in which the desired savings at full employment outpace desired investment. The ZLB prevents the equilibrium real rate from falling to its natural rate where desired savings are equated to investment at full employment, and, therefore, output and inflation fall below their full employment level to restore equilibrium.
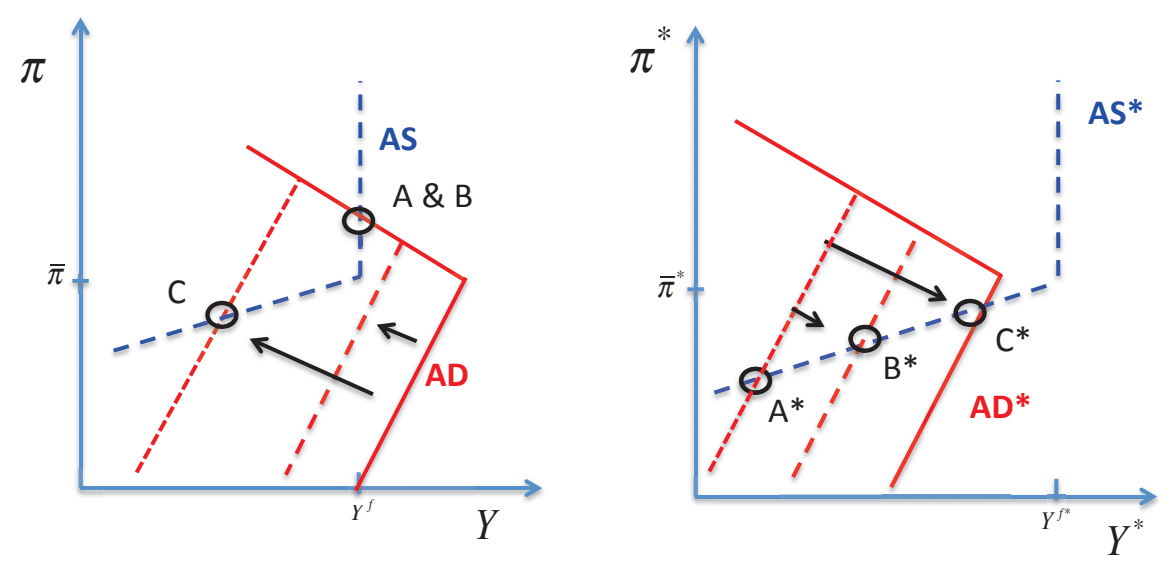

Figure 5 
Can secular stagnation be transmitted across borders? Figure 5 shows the scenario when the foreign economy is in a secular stagnation, while home is not. Consider now the effect of higher capital flows from foreign to home. An increase in capital flows to the domestic economy shifts inward the AD curve; for a given level of output, the real rate needs to be lower to accommodate the extra supply of savings. For a small enough change, monetary policy in the home country lowers rates to maintain full employment (point B in the left panel of Figure 5). ${ }^{7}$ For the foreign economy, the capital outflow raises their natural rate alleviating secular stagnation (point B* in right panel of Figure 5). However, this process can go too far. Further capital flows can drag the domestic economy into secular stagnation (point C) as well. Rather than propagating low interest rates, capital flows instead propagate a recession once the ZLB becomes binding.

More broadly, Figure 5 illustrates that in a global secular stagnation, neo-mercantilist policies policies that attempt to improve one country's net foreign asset position relative to another or run persistent current account surpluses - are beggar-thy-neighbor. Neo-mercantilist policies alleviate the secular stagnation of the country pursuing them by exporting savings, but at the expense of the trading partner.

The real exchange rate is a second channel that can transmit secular stagnation, independently of the capital flows. To the extent that a secular stagnation abroad translates into a higher real exchange rate at home, this directly reduces the natural rate of interest at home, as net export decreases, shifting the AD curve inward. If strong enough, this effect may also lead to a secular stagnation.

\section{International Dimension of Policy in a Secular Stagnation}

In a secular stagnation, each country's policy choices have strong externalities on their trading partners, either positive or negative, beyond normal circumstances due to the ZLB. Expansionary

\footnotetext{
${ }^{7}$ The figure is drawn for exogenous $\mathrm{K}^{*}$ and q, depicting a comparative static for $\mathrm{K}^{*}$. More generally one can solve the equations of the two countries simultaneously for a spread function for $\mathrm{K}^{*}$. Making $q$ endogenous requires one extra equation - the textbook approach has been to introduce a balance of payments equation.
} 
monetary policy, or alternatively currency depreciation, tends to generate negative externalities. Expansionary fiscal policy tends to generate positive externalities.

Expansionary monetary policy, shown in the left panel of Figure 6 is an increase in the inflation target $\bar{\pi}$. This leads to an upward shift in the kink point in the $A D$ curve from $A D_{S S}$ to $A D_{M}$; now the segment of the $A D$ curve consistent with positive interest rates intersects the $A S$ curve on the vertical segment at $B$. Two insights emerge: first, while the full employment equilibrium is a possibility, an increase in the inflation target does not exclude secular stagnation. It is perfectly rational for households to ignore the new inflation announcement of the central bank and the economy then remains mired in stagnation. Moreover, an increase in the inflation target must be sufficiently aggressive. Otherwise, the kink point will not shift enough, and the $A D$ curve does not intersect the $A S$ curve at $B$.
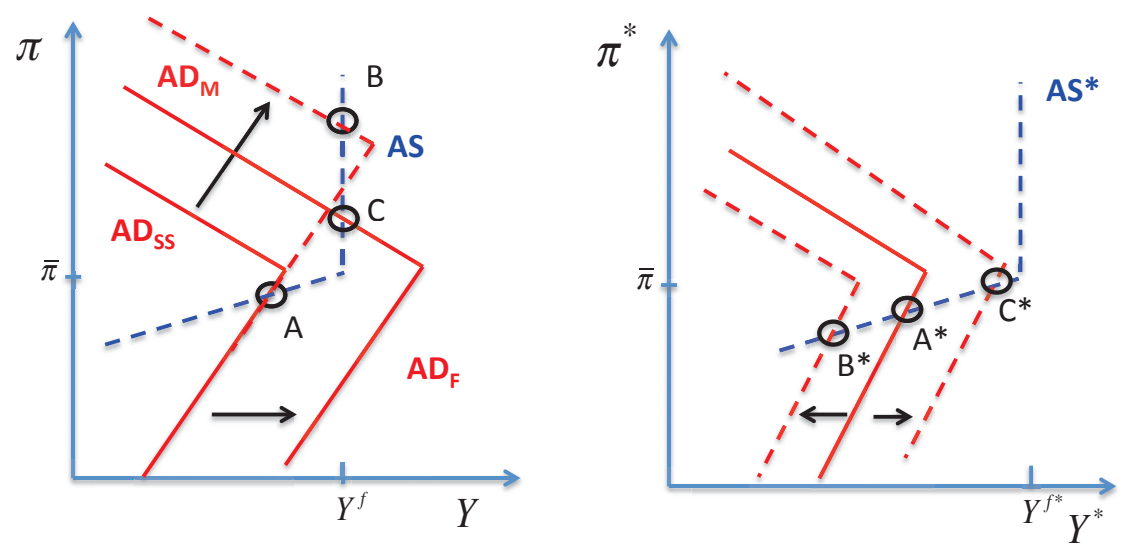

Figure 6

Second, conditional on realizing the inflation target, a successful monetary easing has negative spillovers on the trading partner via two channels. By generating a negative real interest rate for the domestic economy, the higher inflation target triggers a reversal of capital flows, worsening the mismatch between the desired saving and investment abroad, shifting $A D^{*}$ to $B^{*}$ in the right 
panel of Figure 6. Moreover, to the extent expansionary monetary policy depreciates the real exchange rate, this too, reduces demand abroad. ${ }^{8,9}$

Expansionary fiscal policy is shown in the left panel of Figure 6. This policy shifts the entire $A D$ schedule to the right from $A D_{S S}$ to $A D_{F}$ (not just the kink point) with two important implications. First, if policy is aggressive enough, it eliminates the possibility of a secular stagnation altogether at home and ensures full employment. Second, the success of this policy is not contingent on reducing equilibrium real interest rates, $r$, or, more generally, the real exchange rate. Instead, it is an expenditure boosting policy that relies on increasing the natural interest rate $r^{f}$, which closes the output gap since the degree of slack in a secular stagnation depends on the gap: $r^{f}-r$. Thus, if fiscal policy is aggressive enough, it not only eliminates stagnation, it also moves the economy off the ZLB. Fiscal policy, in contrast to monetary policy, may increase the domestic real interest rate, leading to capital inflows from abroad yielding positive externalities for trading partners as shown by point $C^{*}$ in the right panel of Figure 6. Moreover, to the extent that the real exchange rate in the country undertaking the fiscal expansion appreciates, this leads to further beneficial spillovers via trade. ${ }^{10}$

\section{III: Outlook for Global Economic Growth}

Our analysis has disturbing implications for growth going forward. If as many believe reductions in confidence in a range of emerging markets will drive a reduction in capital inflows and an increase in capital outflows going forward, the result will be unambiguously contractionary for the industrialized world as the increase in the trade deficit cannot be significantly mitigated by reductions in interest rates given that they are close to their lower

\footnotetext{
8 If monetary policy is successful, the outflow of capital from the domestic economy increases demand in the domestic economy. This has no effect on $\pi$ or $Y$, but it raises the $r^{f}$, so we omit it from the graph.

${ }^{9}$ A full reversal of capital flows is not needed to generate this result since the capital flow depends on the spread between the interest rates of the two countries. Moreover this result holds even under perfect capital market integration as shown in EMSS.

${ }^{10}$ If the fiscal policy response is not strong enough to increase real interest rate, but instead decreases rates as happens for a small fiscal expansion, then whether there are positive spillovers depends on a horse race between the stimulative effect real appreciation vs. the negative effect of lower real interest rate.In the case of fully integrated capital market as in EMSS, fiscal policy always has positive spillovers and the sign is unambiguous.
} 
bound. It is likely that increased capital flight from emerging markets will also be associated with a weakening of their economies, leading to a currency appreciation in the industrial world. The upshot is that capital mobility may be associated with a generalized weakening of the global economy.

This situation is quite different from the situation at other moments like the Latin American debt crisis of the 1980s or the Asian financial crisis of the 1990s when capital outflows from emerging markets coincided with reductions in US interest rates and a resulting increase in asset values. It is therefore perhaps not surprising that the US stock market seems more sensitive to developments in China than would be implied by historical experience or traditional open economy models.

Our analysis also carries implications for international economic policy. For the industrial world, capital inflows are likely to be contractionary in a way that cannot be offset by monetary policy. The implication is that policies to maintain the flow of capital to emerging markets through encouragement of structural reforms, provision of official finance, and debt relief are more important for domestic prosperity than is the case when secular stagnation is not an issue. The irony of course is that maintaining political support for such policies becomes more difficult in difficult times at home.

A further implication of our analysis is that, in the presence of secular stagnation, there will be a systematic tendency for countries to rely excessively on monetary stimulus relative to fiscal stimulus. To see this, imagine that a country is at the margin indifferent between fiscal and monetary stimulus taking account of all domestic considerations. What would be the preferences of its trading partners? Clearly they would prefer fiscal stimulus which can be expansionary because it (i) falls partially on goods that will be imported and (ii) may lead to an increase in the real interest rate that attract foreign capital, reducing the excessive savings problem of the trading partner. Meanwhile, monetary policy will be expansionary for the country undertaking it 
via an increase in competitiveness and/or lower real interest rates that trigger capital outflows, with both channels working at the trading partner's expense.

This observation resonates with the widespread view of central bankers that they are being asked to carry too much of the burden of restoring growth in the industrial world and with widespread fears about "currency wars". Cooperative efforts to internalize these externalities and achieve more significant fiscal expansion have the potential to achieve greater gains in output and to help countries achieve their national economic objectives.

In EMSS we take up the concern that fiscal policy is infeasible because of government budget constraints and questions of fiscal sustainability by making the point that, following the analysis of Delong and Summers (2012), fiscal policy may actually reduce debt to GDP ratios, and by noting that even temporary fiscal expansions of sufficient magnitude will, under plausible assumptions, move economies in secular stagnation into normal conditions.

Ultimately the relevance of the analysis in this paper depends on the plausibility of secular stagnation concerns. This of course is a matter of judgment. We conclude by observing that the combination of the long term downward trend in real interest rates, the continuation of very sluggish growth even in the presence of zero rates, market forecasts that that neither real interest rates nor inflation will normalize over periods of more than a decade anywhere in the industrial world, and growing concerns about the sustainability of even the slow recovery from the financial crisis in the United States make us believe that economists and policymakers need to give substantial weight to the possibility that secular stagnation will be the defining economic challenge for macroeconomic policy over the next decade. 


\section{REFERENCES}

Caballero, R., E. Farhi and P. Gourinchas, 2015. "Global Imbalances and Currency Wars at the ZLB.”NBER WP 21670.

Delong, B. and L. Summers, 2012. "Fiscal Policy in a Depressed Economy." Brookings Papers on Economic Activity, 2012(1), 233-297.

Eggertsson, G. and N. Mehrotra. 2014. “A Model of Secular Stagnation.” NBER WP 20574.

Eggertsson, G., N. Mehrotra, S. Singh, and L. Summers. 2015 “A Contagious Malady? Open Economy Dimension of Secular Stagnation,” mimeo, Brown University.

Krugman, P. 1998. “It's Baack! Japan's Slump the Return of the Liquidity Trap.” Brookings Papers on Economic Activity, 1998(2), 137-187.

Romer, D. 2013 "Short-run fluctuations," mimeo, Berkeley.

Summers, L. 2014. "U.S. Economic Prospects: Secular Stagnation, Hysteresis, and the Zero Lower Bound.” Business Economics, 49(2). 